\title{
Influence of soil moisture on energy requirement of rotary tilling
}

\author{
Shiddanagouda Yadachi 不 \\ Department of Agriculture Engineeering CHEFT-Devihosur, Haveri. \\ Indra Mani \\ Division of Agriculture Engineeering IARI New Delhi. \\ Tapan K Khura \\ Division of Agriculture Engineeering IARI New Delhi.
}

\begin{tabular}{|c|c|}
\hline ARTICLE INFO & ABSTRACT \\
\hline $\begin{array}{l}\text { Received : } 23 \text { July } 2021 \\
\text { Revised : } 24 \text { September } 2021 \\
\text { Accepted : } 04 \text { October } 2021 \\
\text { Available online: } 19 \text { December } 2021 \\
\text { Key Words: } \\
\text { Torque } \\
\text { Power } \\
\text { Speed ratio } \\
\text { Specific tilling energy }\end{array}$ & $\begin{array}{l}\text { The rotary tiller with ' } L \text { ' shaped blades was examined for torque, power and } \\
\text { specific tilling energy requirements to attain optimum soil-machine operational } \\
\text { parameters. The three levels of moisture content }(11.4 \%, 12.8 \% \text { and } 14.6 \% \\
\text { (d.b)), three speed ratios of } 20\left(\lambda_{1}\right), 12\left(\lambda_{2}\right) \text { and } 9\left(\lambda_{3}\right) \text { at different passes (first, } \\
\text { second and third) with rotational speed of } 262 \mathrm{rpm} \text { were selected for study. The } \\
\text { observations indicated inverse relation between torque and power requirement } \\
\text { to moisture content. The lowest value of torque of } 16.54 \mathrm{~N}-\mathrm{m} \text { and } 26.66 \mathrm{~N}-\mathrm{m} \\
\text { was associated with sandy loam and clay loam soil under third pass and } \\
\text { moisture content of } 14.6 \text { per cent. Similarly, the minimum power requirement } \\
\text { of } 0.452 \mathrm{~kW} \text { and } 0.699 \mathrm{~kW} \text { was observed under analogous conditions of rotary } \\
\text { tiller. The energy requirement was found to decrease with higher number of } \\
\text { passes due to the breakdown of the hard pan and clod aggregate size. The } \\
\text { specific tilling energy is strongly correlated with forward speed and less } \\
\text { dependent on the number of the passes of rotary tilling. }\end{array}$ \\
\hline
\end{tabular}

\section{Introduction}

Rotary tillage is superior to conventional tillage methods and viable option to achieve maximum soil pulverization during seedbed preparation (Destan and Houmy, 1990). Rotavator is very effective in achieving thorough soil pulverization with 15-20 per cent less fuel than any other traditional implements. In recent years, rotavator has been in extensive use on Indian farms. At present, a total of 6720 rotavators are in operation exclusively in Punjab (India) (Anon, 2011) with an increasing trend. The recent increasing trends of requirement of rotavators specify their scope in crop production. It has an ample opportunity and gaining huge scope under horticulture production, particularly, use of offset rotavators in orchard cultivation and trend has been increased in recent years (Ramesh et al., 2015; Krutz, 2006). Rotavator is used as both the primary and secondary tillage machine, which has huge potential for cutting, mixing topsoil and preparing the seedbed directly. Moreover, ratavator has a mixing ability seven times more than a plough (Matin, 2015). Use of rotavator has increased because of its ability to reduce the soil traffic to a great extent by blending the soil (Topakci, 2008; Culpin, 1981). Despite its high power requirement, rotavator is considered to be time and energy efficient as it prepares seedbed in single pass, thus saves time, labour and fuel, thereby reducing cost (Shiva et al., 2014). Soil with modest hardness can be prepared more rapidly by rotavators (Surendra, 2007). Thus, rotavator also reduces the time required to prepare an optimum seedbed by combining the primary and secondary tillage operations in one pass (Gopal and Shyam, 2012). Rotavator results in 25-30 per cent higher quality seed beds than conventional tillage methods (Sharda and Singh, 2004; Sirisak et al., 2010; Sahay, 2009). Sinha and Ram (1998) reported that, rotavator saves $30-35$ per cent of time and 20-25 per cent cost of operation in comparison to conventional tillage which permits the farmer to increase farm acreage with less dependency on

Corresponding author E-mail: shiddu86@gmail.com

Doi: https://doi.org/10.36953/ECJ.2021.22340

This work is licensed under Attribution-Non Commercial 4.0 International (CC BY-NC 4.0)

(C) ASEA 
hired farm labor, helps in performing more timely operations and obtaining higher yields.

The kinematic parameters like forward speed, rotor speed and speed ratio $(\lambda)$ influence the soil cutting process of rotary tillers to a great extent. A ratio of blade peripheral speed to the forward speed of the machine (speed ratio), is most important rotavator operational parameter for quantifying its soil working performance. It is an important rotavator operational parameter for quantifying its performance in terms of soil handling and energy requirements. Practically, for the given configurations of rotavator, the rotor radius remains unchanged and suitable speed ratios can be attained by altering the forward speeds of machine. The blade configuration on the rotor and the shape also greatly affects the soil throwing and power requirements. Lee et al. (2003) designed the minimum tillage technique using Japanese C shaped blades for direct seeding of rice. He studied the influence of forward speed of down cut rotavator on soil cutting and throwing process in sandy loam and clay soils. It was observed that, the tilling at increased rotor and forward speeds led to the scattering of soil out of the seeding furrow and provided thorough pulverization. The down cut rotavator resulted in highest soil breaking ratio $(24.4 \%)$ and its operation with four blades produced the seedbeds of width $80 \mathrm{~mm}$, which was found adequate for direct seeding of rice and applying fertilizer. Shiva et al. (2014) studied the soil pulverization and mixing ability of rotary tiller using ' $\mathrm{L}$ ', ' $\mathrm{C}$ ' and ' $\mathrm{J}$ ' blades under varying rotor speeds $(180,215$ and 250rpm) in clay loam soil for optimization of best possible combinations of rotor speed and blade shape. The rotary tilling was compared with control (tillage with one pass of disc harrowing followed by one pass of cultivator). The blade shapes affected the soil pulverization and soil mixing positively. The ' $J$ ' shaped blade gave lower pulverization index of $8.57 \mathrm{~mm}$ and higher mixing ability of 93.48 per cent at $250 \mathrm{rpm}$ as compared to ' $\mathrm{C}$ ' shaped blades ( $9.84 \mathrm{~mm}$ and 92.24 per cent) and ' $L$ ' shaped blades $(10.18 \mathrm{~mm}$ and 90.11 per cent) and control $(15.36 \mathrm{~mm})$. The ' $\mathrm{J}$ ' shaped blade at $250 \mathrm{rpm}$ was considered as the best combination for rotary tiller operation. Sirisak and Niyamapa (2010) studied the influence of rotary tiller blade geometry on seed bed characteristics in Thailand soils, in which three different blades (Japanese C- shaped blade, the European C-shaped blade and the European L-shaped blade) were evaluated for their performance. The machine forward speeds of 0.069 and $0.142 \mathrm{~ms}^{-1}$ and rotational speeds of 150,218 , 278 and $348 \mathrm{rpm}$ were considered for down cut rotary tiller. The torque and energy exerted on the rotary tiller were higher in clay loam soil than in sandy soil and energy requirements increased with forward speed. Salokhe and Ramalingam (2001) investigated the effect of reverse rotation of rotary tiller on seed bed quality, incorporation of crop residues and weeds. The new type of blades was designed for the reverse rotary tiller and evaluated it performance at forward speeds of 1.0, 1.5 and 2.0 $\mathrm{km} / \mathrm{h}$. Reverse rotary tiller with new design performed better than ' $\mathrm{C}$ ' type blades in terms of chopping and burial of weeds. The ' $\mathrm{C}$ ' type rotary tiller performed slightly better than the reverse rotary tiller in terms of puddling index, viscosity, falling cone penetration with a minimum cone index of $116.7 \mathrm{kPa}$ compared to $180.1 \mathrm{kPa}$ for rotary tiller and bulk density reduction. Ade and Pezzi (1999) examined the influence of forward speed and rotor speed on soil inversion by rotary tillers. He observed that, the forward speed and rotor speed of rotary tiller had great influence on obtaining higher quality of soil inversion with 95.8 per cent. Also, increased pitch due to decrease in the rotor speed resulted in decreased power requirements, but power increased with increased pitch. Considering soil inversion, specific energy requirements and rate of work, they concluded that, the lower rotor speed and higher forward speeds as the most favourable range of operational parameters for rotary tiller. After a brief review of importance of the kinematic parameters and blade geometry on soil properties it was found that, researchers more often focussed on energy requirements than soil quality. However, some studies highlighted the importance of forward speed and speed ratios on soil inversion and soil handling quality of rotavator, thus, inclusion of speed ratio as machine operational variable in the study was justified. It was observed that, ' $C$ ', ' $\mathrm{L}$ ' and ' $\mathrm{J}$ ' shaped blades produced wide range of soil handling with variation in power requirements. The ' $L$ ' shaped blade was selected for the study on account of its extensive use on Indian farms.

There is no study which could give energy requirements of rotary tillage in different soil and 
moisture conditions in controlled environment. Therefore, there should be optimum machine operational parameters for different soil texture and moisture contents, which might minimise soil throw while producing an acceptable level of soil pulverisation at minimum energy expenditure. The present study compares the torque, power and specific tilling energy requirements of rotary tiller when operated at different soil and machine operational parameters with the aim of determining their effectiveness for rotary tillage operations.

\section{Material and Methods}

The experiments were conducted in the soil bin to record the responses. The soil bin located in soil dynamics laboratory in the Division of Agricultural Engineering, Indian Agricultural Research Institute, New Delhi was utilized for study. The investigation on rotary tilling was made under controlled conditions with accurate measurement of the variables for two soil textures. The soil bin consisted of a rectangular platform filled with soil, rotary tilling set up, soil trough, soil processing carriage, soil processing trolleys, power transmission system, control unit and instrumentation for measurement of different responses. The soil bin dimensions were $30 \mathrm{~m}$ long, $2.3 \mathrm{~m}$ wide and $1 \mathrm{~m}$ deep. The $5 \mathrm{hp}, 1440 \mathrm{rpm}$ electric motor was used as power transmission for rotary tillage units. The soil bin equipment such as rotary tiller, soil leveller, roller compacter, tool bar and water sprayer were used to get the desired experimental conditions. The range of forward speeds of tool bar frames achieved between $0.31 \mathrm{~ms}^{-}$ 1 and $0.76 \mathrm{~ms}^{-1}$. The effect of rotary tilling on torque, power requirements and energy

Table 1: Plan of experiments

\begin{tabular}{|c|c|c|c|c|}
\hline $\mathbf{S N}$ & Variables & Levels & Details of levels & Responses measured \\
\hline 1 & Soil type & 2 & Sandy loam $\left(\mathrm{S}_{1}\right)$, Clay loam $\left(\mathrm{S}_{2}\right)$ & \multirow{4}{*}{$\begin{array}{l}\text { Seed bed characteristics } \\
\text { Volume of soil handled } \\
\text { Torque and power } \\
\text { requirements } \\
\text { Specific tilling energy }\end{array}$} \\
\hline 2 & Moisture content & 3 & $11.4 \%(\mathrm{db}) \mathrm{M}_{1}, 12.8 \%(\mathrm{db}) \mathrm{M}_{2}, 14.6 \%(\mathrm{db}) \mathrm{M}_{3}$ & \\
\hline 3 & Number of Passes & 3 & First pass $\left(\mathrm{P}_{1}\right)$, Second pass $\left(\mathrm{P}_{2}\right)$, Third pass $\left(\mathrm{P}_{3}\right)$ & \\
\hline 4 & Speed ratio & 3 & $20\left(\lambda_{1}\right), 12\left(\lambda_{2}\right)$ and $9\left(\lambda_{3}\right)$ & \\
\hline
\end{tabular}

characteristics were studied in sandy loam and clay soils at a tilling depth of $14 \mathrm{~cm}$, forward speeds of $0.34 \mathrm{~ms}^{-1}, 0.52 \mathrm{~ms}^{-1}$ and $0.76 \mathrm{~ms}^{-1}$, and rotational speed of $262 \mathrm{rpm}$ (Table 2). The torque acting on rotating shaft during tilling by rotary tiller was sensed by a torque sensor fixed in between rotary tiller shaft and output shaft of gearbox (Figure $1 \&$ 2a). The forward speed of experimental set up was measured by marking distance of $1000 \mathrm{~cm}$ part (A, B) in middle of test run. Thus forward speed was calculated from the time required for experimental test rig to travel the distance $(100 \mathrm{~cm})$ between markers A, B. The rotational speed of the shaft was measured by a tachometer.

Table 2: Kinematic parameters and corresponding bite lengths of rotary tiller

\begin{tabular}{|l|l|l|l|l|}
\hline SN & $\begin{array}{l}\text { Forward } \\
\text { speed }\left(\mathbf{m s}^{-1}\right)\end{array}$ & $\begin{array}{l}\text { Rotor } \\
\text { speed } \\
\text { N(rpm) }\end{array}$ & $\begin{array}{l}\text { Bite } \\
\text { length } \\
\text { L(mm) }\end{array}$ & $\begin{array}{l}\text { Speed } \\
\text { ratio } \\
\boldsymbol{\lambda}\end{array}$ \\
\hline 1 & 0.34 & 262 & 25.95 & 20 \\
\hline 2 & 0.52 & 262 & 39.69 & 12 \\
\hline 3 & 0.75 & 262 & 57.25 & 9 \\
\hline
\end{tabular}

\section{Seedbed characteristics}

After each test run, the seed bed characteristics such as seed bed height, width, cross sectional area, and volume of soil handled by rotary tiller were recorded. For recording these characteristics, an instrument called seedbed profiler was fabricated. The seed bed profiler (Figure $3 \& 4$ ) consisted of hollow aluminium rods, rectangular $(45.72 \mathrm{~cm} \mathrm{x}$ $10.5 \mathrm{~cm}$ ) flat frame and hollow square base of $100 \mathrm{~mm} \times 8 \mathrm{~mm}$. The rectangular frame was drilled with $12 \mathrm{~mm}$ holes at every $38 \mathrm{~mm}$ over the top surface of both the flats to ensure easy sliding of aluminium rods. The aluminium rods of $10 \mathrm{~mm}$ diameter and $200 \mathrm{~mm}$ length were marked with graduations in every $5 \mathrm{~mm}$ along their length. After each run of test rig, the profiler was placed above the seed bed path and bed height was recorded by graduations. The graduations over the top flat was taken as bed height(h), and depth of operation(d), was noted down. The volume of soil handled by flange per every meter of run was calculated as follows; 
Volume of soil handled/m

$=$ Cross sectional area of seed bed, $\mathrm{sq} \mathrm{m}$

* length, $\mathrm{m}$

$\mathrm{V}=\frac{(\mathrm{h}+\mathrm{d}) \mathrm{w}}{10000} * \mathrm{~L}$

Where, V= Volume of soil handled $\left(\mathrm{m}^{3}\right) ; \mathrm{h}=$ height of seed bed $(\mathrm{m})$; $\mathrm{d}=$ Depth of operation $(\mathrm{cm})$; w = Width of tilled soil strip $(\mathrm{cm}) ; \mathrm{L}=$ Length of run $(\mathrm{m})$

\section{Torque and energy requirement}

The experimental runs were carried out as per the plan of experiments under different levels of soil moisture. During each run, video clips of torque readings were captured. The average torque values were recorded from video clip readings manually. The power required by flange was calculated from following equation;

Power required by rotary tiller flange, $\mathrm{P}=\frac{2 \pi \mathrm{nT}}{60000}$

Where, $\mathrm{P}=$ power (average) requirement $(\mathrm{kW}) ; \mathrm{T}=$ torque (average) $(\mathrm{N}-\mathrm{m}) ; \mathrm{n}=$ rotary speed $(\mathrm{rpm})$

From the average power requirement $(\mathrm{P})$, the specific energy requirement was calculated by two methods.(i) Specific energy based on seedbed
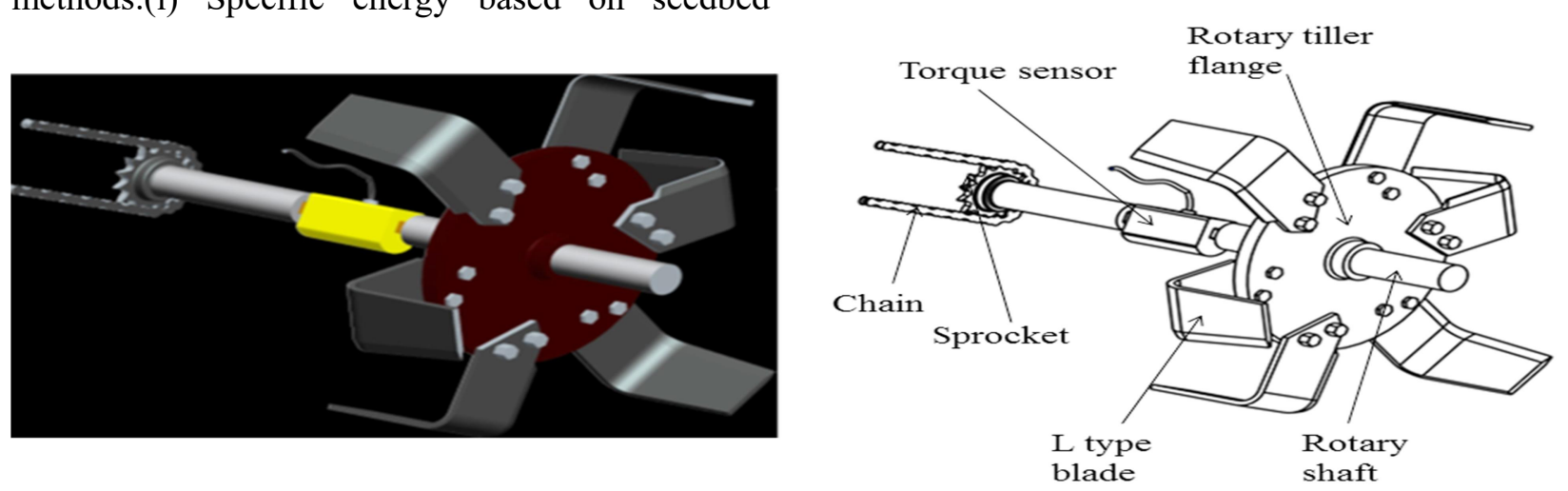

Figure 1: Isometric and schematic view of torque measurement system of rotary tiller
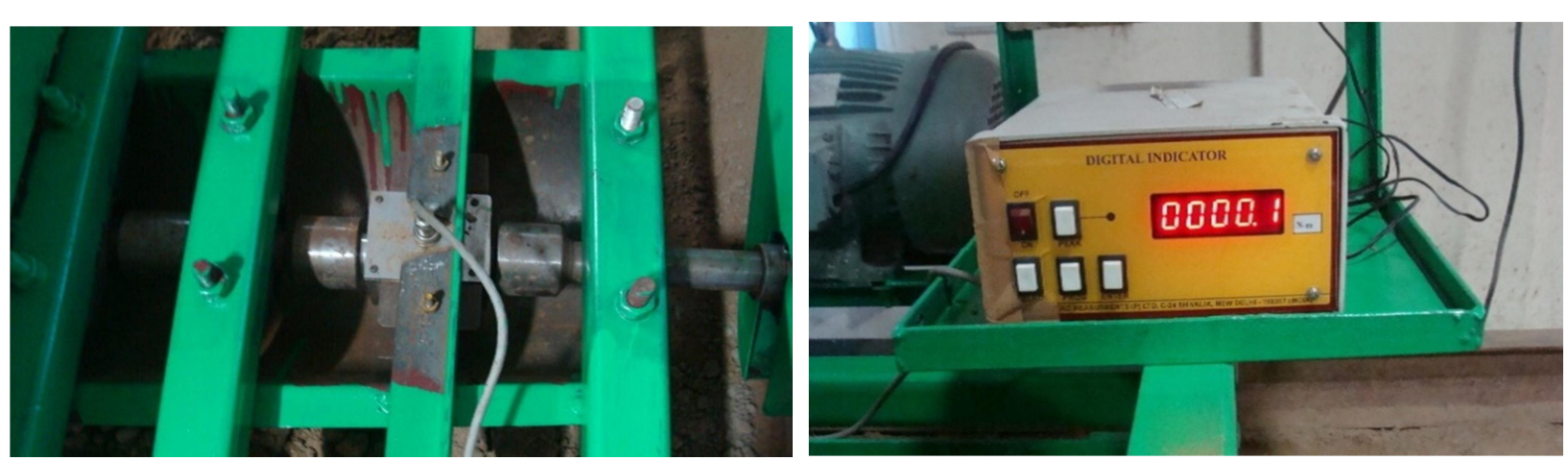

Figure 2: (a) Torque sensor (b) Digital indicator for torque

350

Environment Conservation Journal

characteristics was calculated using eqn. 3, (Sirisak and Niyamapa, 2010);

$\mathrm{Es}=\frac{P}{v} * \frac{1}{V}$

Where, Es $=$ Specific energy requirement $\left(\mathrm{kJ} \mathrm{m}^{-3}\right) ; \mathrm{P}=$ Power (average) requirement $(\mathrm{kW})$;

$v=$ Forward speed of rotor $\left(\mathrm{m} \mathrm{s}^{-1}\right) ; \mathrm{V}=$ Volume of soil handled per $\mathrm{m}$ seed bed $\left(\mathrm{m}^{3} \mathrm{~m}^{-1}\right)$ using eqn. (1)

The specific energy based on the concept of bite length of rotary tiller blade was calculated as follows;

The bite length of fabricated rotary tiller was calculated using eqn. 4 ,

$$
\text { Bite length }(\mathrm{L}), \mathrm{mm}=\frac{\mathrm{V}}{\mathrm{n}} * \frac{60}{\mathrm{Z}}
$$

Where, $v=$ forward speed of rotary tiller $(\mathrm{mm} / \mathrm{s}) ; \mathrm{n}=$ rotary tiller speed (rpm); $Z=$ number of blades which would cut identical paths if $v=0,(\mathrm{Z}=3)$.

Specific tilling energy in terms of bite length was computed from eqn. 5, (Sirisak and Niyamapa, 2010);

Specific tilling energy, $\mathrm{kJ} / \mathrm{m}^{3}=\frac{\text { Tilling energy per bite }}{\text { Soil volume worked per bite }}$ 

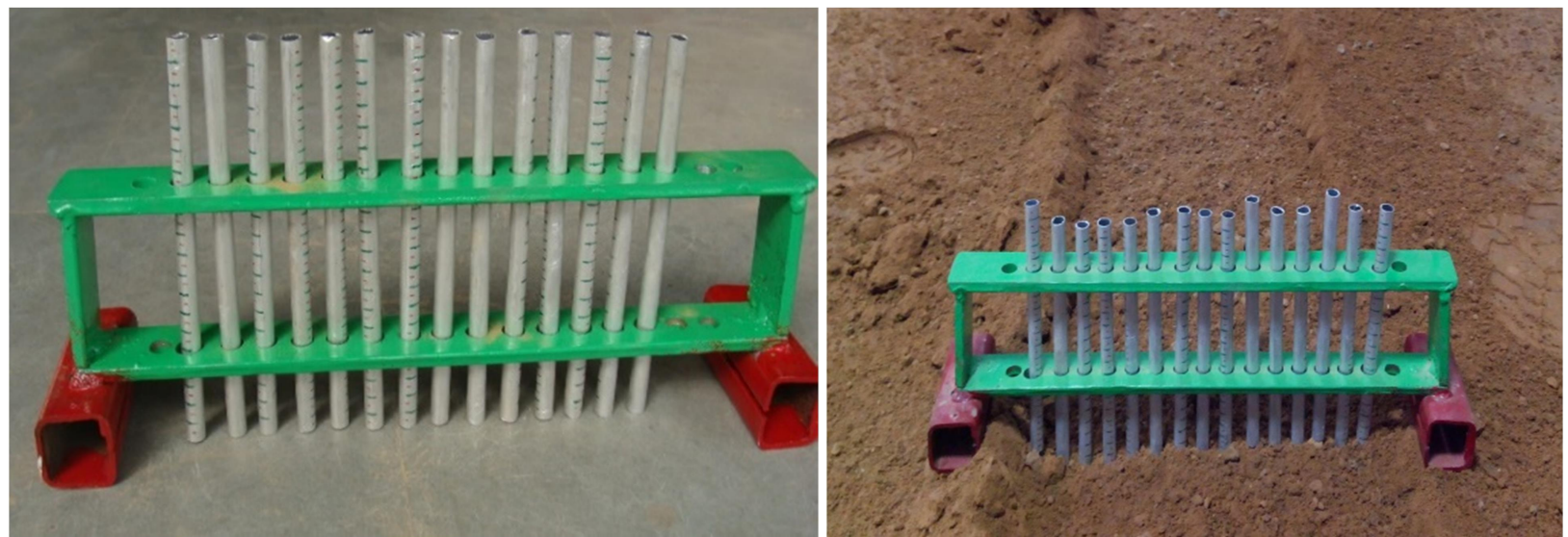

Figure 3: Seed bed profiler

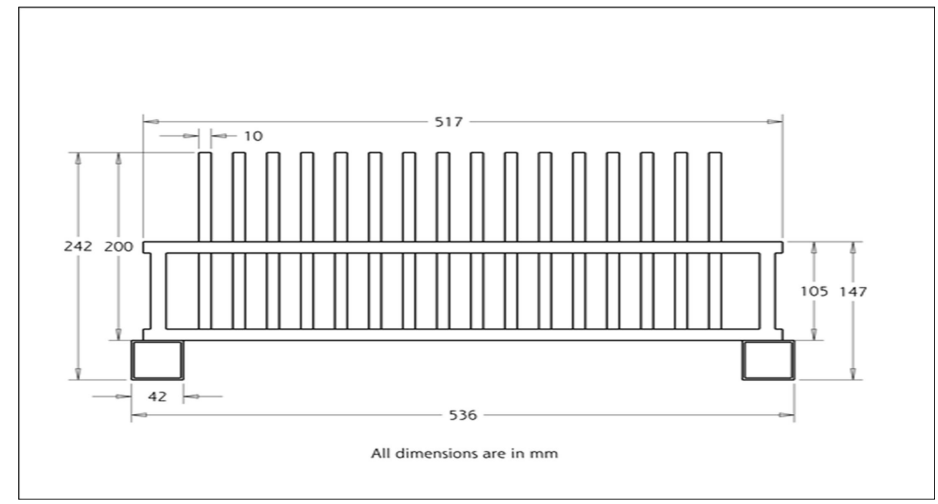

Figure 4: Line diagram of seed bed profiler

\section{Results and Discussion}

Torque requirement varied throughout the soil cutting process under different speed ratios, passes and soil moisture. Maximum torque was recorded acting on rotary shaft in clay loam soil than in sandy loam (Figure 5a \&5b). It was observed that with the forward speed, torque exerted on rotary tilling shaft also increased. This is because of the reason that as the forward speed increases, speed ratio decreases and bite length of blade increases and subsequently volume of the soil slice cut also increases at higher bite lengths, leading to increase in torque.

Higher torque was observed initially when the soil was dry, but it decreased with the increase in soil moisture for all the levels of pass. The minimum torque was recorded under third pass $\left(\mathrm{P}_{3}\right)$ for all the levels of soil moisture (Fig 6a \& 6b). Irrespective of the levels of soil moisture, the torque value decreased in subsequent passes. For each pass, the torque requirement increased with forward speed.
From the first pass to second pass, $10.9 \%, 6.7 \%$ and 3\% decrease in the torque was observed soil moisture contents $M_{1}, M_{2}$ and $M_{3}$, respectively under clay loam soil $\left(\mathrm{S}_{2}\right)$. The higher torque reductions of $11.8 \%, 10.8 \%$ and $6.5 \%$ were observed in pass $\left(\mathrm{P}_{3}\right)$ for $\mathrm{M}_{1}, \mathrm{M}_{2}$ and $\mathrm{M}_{3}$, respectively for clay loam soil $\left(\mathrm{S}_{2}\right)$. The torque reduction from $\mathrm{M}_{1}$ to $\mathrm{M}_{3}$ was $14.13 \%, 11.9 \%$ and $7.5 \%$ for $\mathrm{P}_{1}, \mathrm{P}_{2}$ and $\mathrm{P}_{3}$, respectively for sandy loam soil $\left(\mathrm{S}_{1}\right)$. Torque exerted was influenced significantly by all study variables at $1 \%$ level for both the soil textures. The effect of interaction of soil moisture and pass was significant at $1 \%$ level for both soil textures. The interaction effect of soil moisture and speed ratio, passes and speed ratio on torque requirement was significant under clay loam soil $\left(\mathrm{S}_{2}\right)$ at $1 \%$ level. Interaction of all variables had significant effect on torque requirement at 1 per cent level (Table 3). The higher values of power requirement were associated with lower moisture contents and the same was decreased with increased 
Table 3: F-Values of torque, power and specific tilling energy requirements

\begin{tabular}{|l|l|l|l|l|l|l|}
\hline \multirow{2}{*}{ Sources } & \multicolumn{4}{|l|}{ Torque } & Power & \multicolumn{2}{l|}{ Specific energy } \\
\cline { 2 - 7 } & $\mathrm{S}_{1}$ & $\mathrm{~S}_{2}$ & $\mathrm{~S}_{1}$ & $\mathrm{~S}_{2}$ & $\mathrm{~S}_{1}$ & $\mathrm{~S}_{2}$ \\
\hline $\mathbf{M}$ & $398.77^{* *}$ & $8.0^{* *}$ & $393.26^{* *}$ & $1.01^{* *}$ & $486.09^{* *}$ & $1.03^{* *}$ \\
\hline $\mathbf{P}$ & $1.14^{* *}$ & $7.15^{* *}$ & $1.12^{* *}$ & $7.97^{* *}$ & $1.29^{* *}$ & $8.04^{* *}$ \\
\hline $\boldsymbol{\lambda}$ & $98.74^{* *}$ & $781.94^{* *}$ & $97.23^{* *}$ & $1.21^{* *}$ & $9.82^{* *}$ & $4.82^{* *}$ \\
\hline $\mathbf{M}^{*} \mathbf{P}$ & $90.99^{* *}$ & $3.33^{* *}$ & $89.86^{* *}$ & $2.58^{* *}$ & $106.65^{* *}$ & $2.67^{* *}$ \\
\hline $\mathbf{M}^{*} \boldsymbol{\lambda}$ & 2.07 & $186.5^{* *}$ & 2.08 & $31.59^{* *}$ & $41.5^{* *}$ & $5.72^{* *}$ \\
\hline $\mathbf{P}^{*} \boldsymbol{\lambda}$ & 0.48 & $191.51^{* *}$ & 0.43 & $38.18^{* *}$ & $56.13^{* *}$ & $3.96^{* *}$ \\
\hline $\mathbf{M}^{*} \mathbf{P}^{*} \boldsymbol{\lambda}$ & $2.22^{* *}$ & $139.61^{* *}$ & 2.02 & $14.93^{* *}$ & $9.93^{* *}$ & $158.73^{* *}$ \\
\hline
\end{tabular}

Note: * Significant at $5 \%$ level; $\quad * *$ Significant at $1 \%$ level
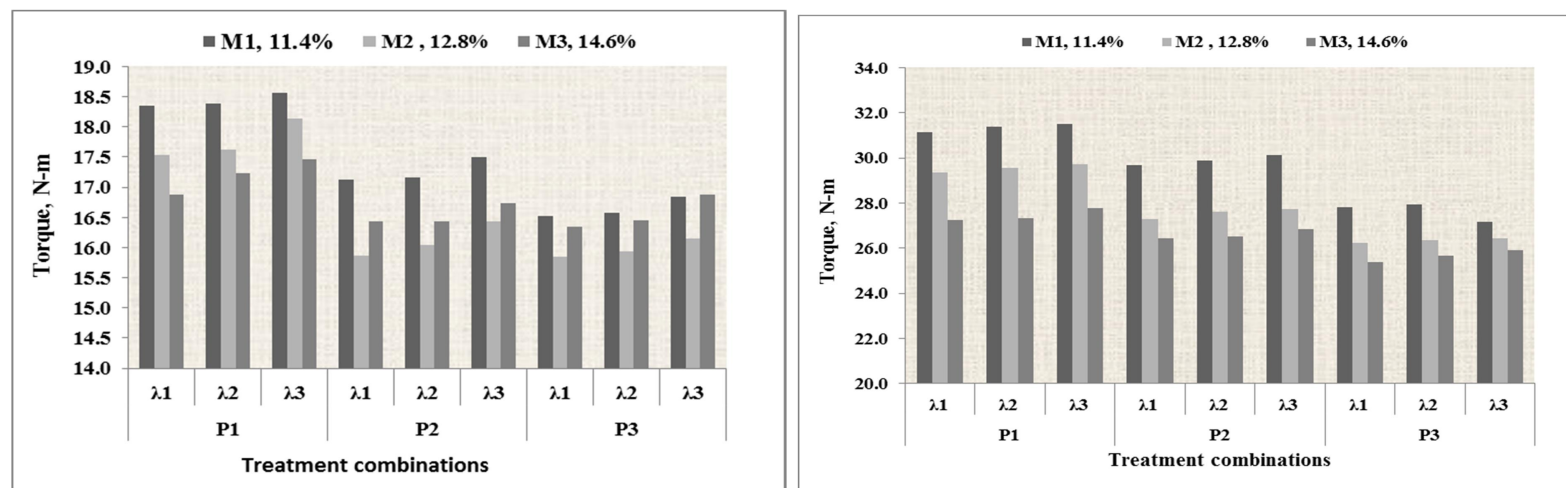

Figure 5: Trends of torque requirements under (a) sandy loam (b) clay loam soil
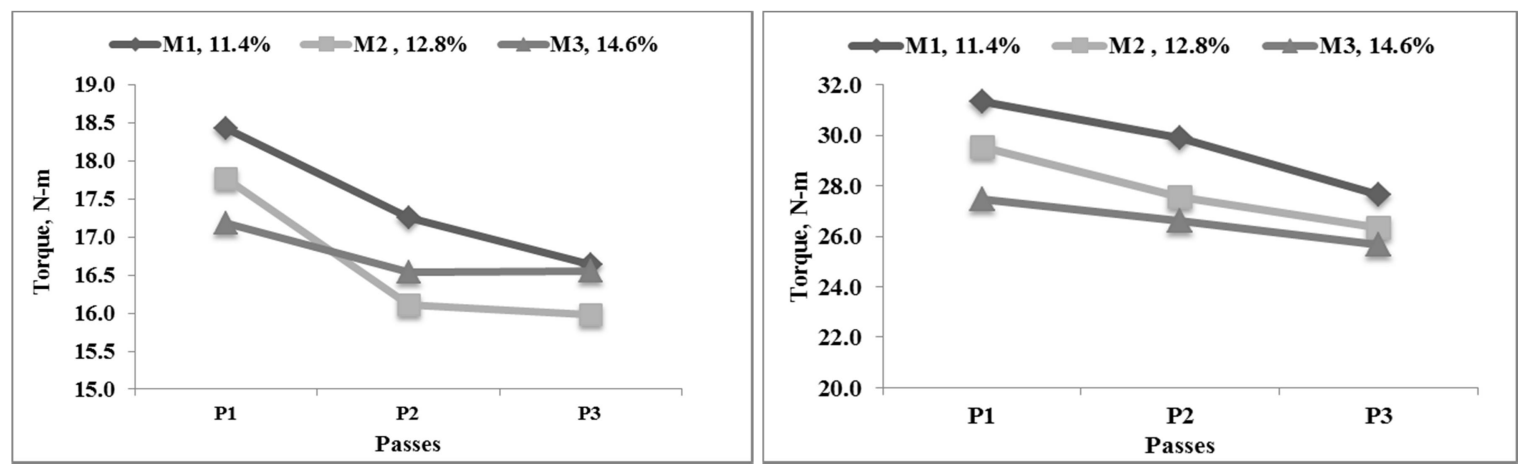

Figure 6: Effect of passes on torque requirement under a) sandy loam b) clay loam soil
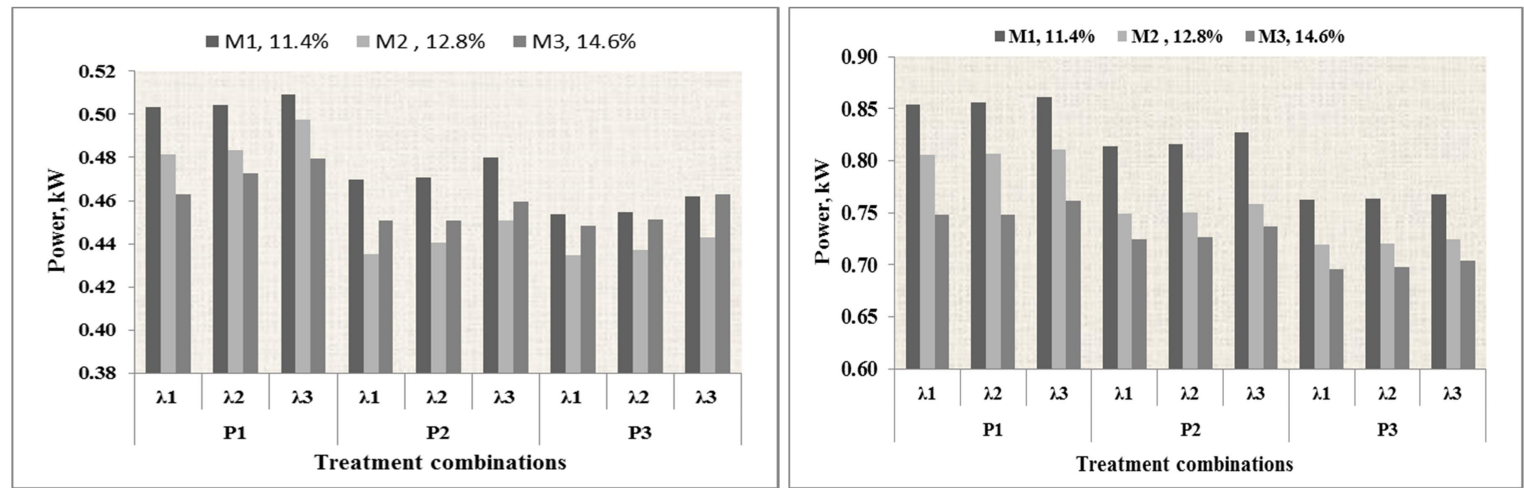

Figure 7: Trends of power requirement under (a) sandy loam, (b) clay loam soil 

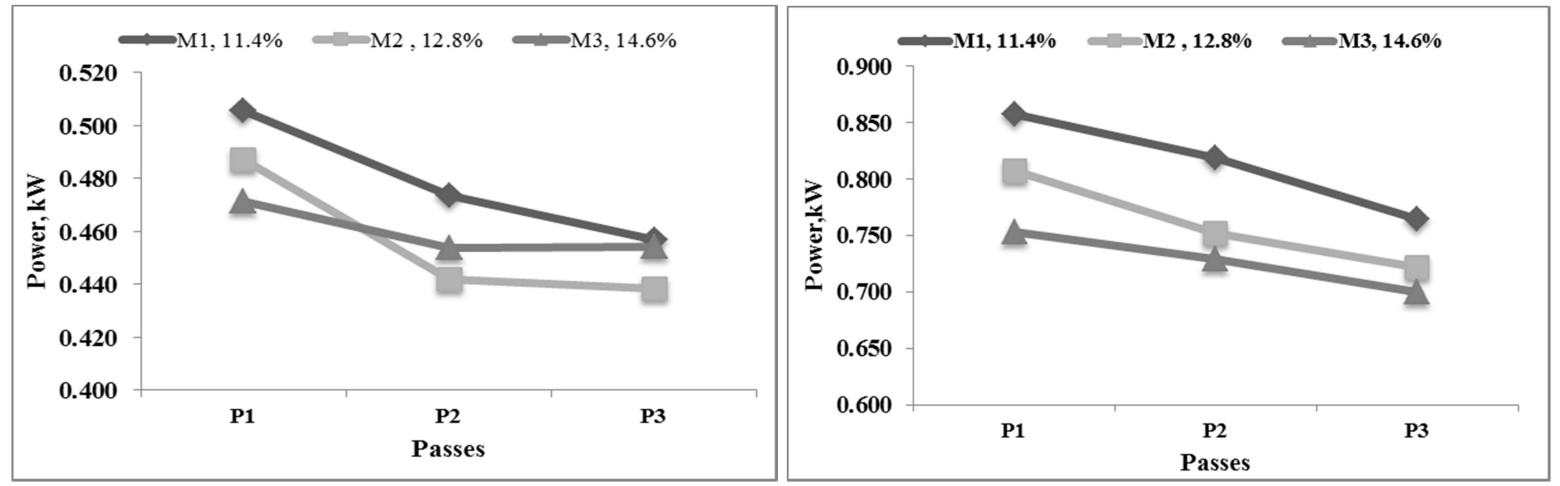

Figure 8: Effect of passes on power requirement for a) sandy loam, b) clay loam soil
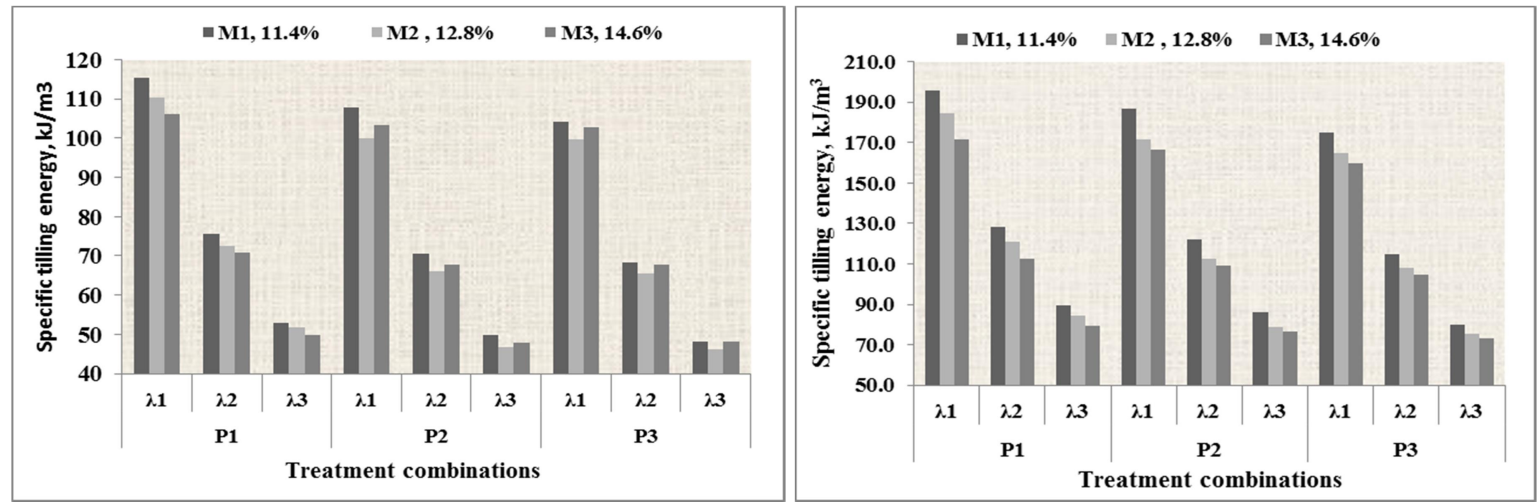

Figure 9: Specific tilling energy under (a) sandy loam, (b) clay loam soil
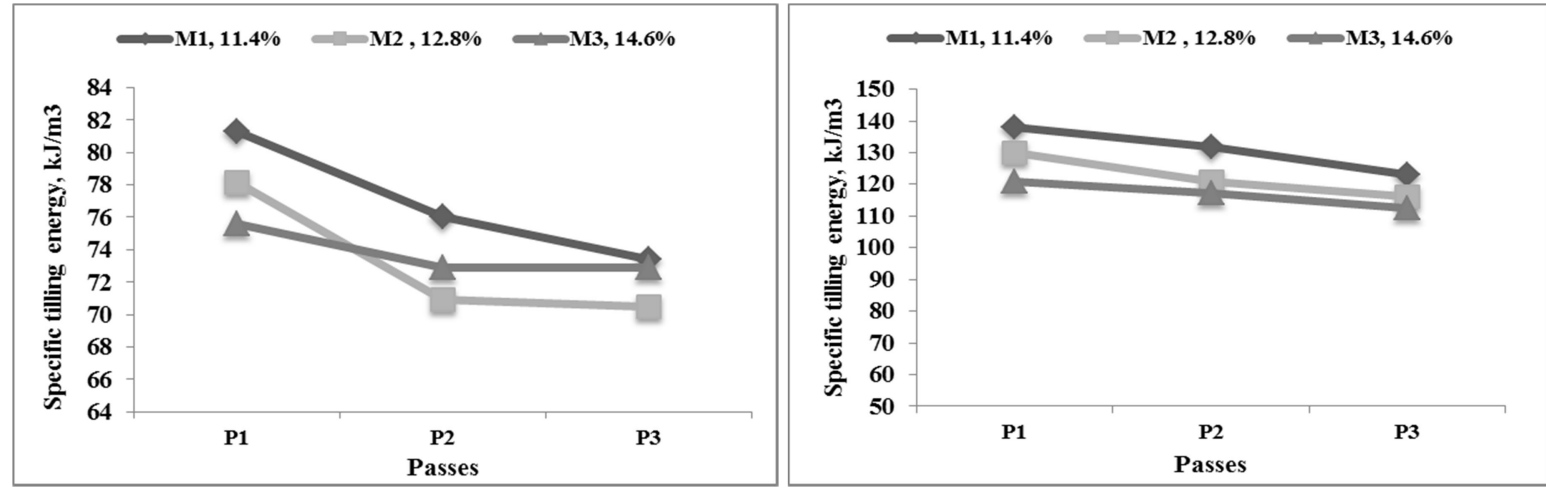

Figure 10: Effect of passes on specific tilling energy under a) sandy loam b) clay loam soil

soil moisture for both the soil textures (Figure $7 \mathrm{a} \& 7 \mathrm{~b})$. The power requirement was maximum for clay loam than in sandy loam soil. The power requirements were higher in first pass, but were decreased in subsequent passes. The minimum power requirements were observed at third pass $\left(\mathrm{P}_{3}\right)$ for all the levels of soil moistures (Figure 8a $\& 8 b$ ). For each pass, the power requirement increased with forward speed. The power requirement decreased with higher levels of soil moistures under both soil textures. The study variables had significant effect on power requirement for both soil textures at $1 \%$ level. The effect of interaction of soil moisture and passes on power requirement was also significant at $1 \%$ level. The interaction of moisture and speed ratio; passes and speed ratio; \& moisture and passes) had significant effect on power requirement under clay loam soil $\left(\mathrm{S}_{2}\right)$. 


\section{Specific tilling energy}

The specific tilling energy decreased with increased soil moistures for both soil textures. For lower levels of soil moistures (dry conditions), the energy required was higher and as soil moisture increased the energy requirements were decreased. The specific tilling energy was higher for clay loam than in sandy loam soil. The size of clay particles was less than $0.002 \mathrm{~mm}$ causing compact arrangement, the contact area between the soil particles in clay soil being more than in sandy loam soil. Therefore, the energy requirement in clay loam soil was higher than in sandy loam soil. The specific tilling energy decreased in subsequent passes being always higher in first pass $\left(\mathrm{P}_{1}\right)$. The lowest value was observed under third pass $\left(\mathrm{P}_{3}\right)$ for all the levels of soil moistures (Fig 10a \& 10b). For each pass, the specific tilling energy was found to be decrease with increased forward speeds and the similar results were observed by Sirisak and Niyamapa (2010). In sandy loam soil, increased forward speed from $\lambda_{1}$ to $\lambda_{2}$, energy decreased to the tune of $34.64 \%$, whereas with increase in forward speed from $\lambda_{1}$ to $\lambda_{3}$ a decrease of $53.67 \%$ was observed. The energy reductions were found to be $36.08 \%$ and $54.7 \%$, respectively for increase in forward speed from $\lambda_{1}$ to $\lambda_{2}$ and from $\lambda_{1}$ to $\lambda_{3}$ for clay loam soil. Specific tilling energy was significantly influenced by all study variables at $1 \%$ level (Table 3). The interaction effect of soil moisture content with passes had significant effect on specific tilling energy at 1\% level for both the soil textures. The two way interaction of all study

\section{References}

Ade, G., \& Pezzi, F.(1999). Tests on rotary tillers equipped with different blades. Agric. Engg, Abstracts. 14(12):495.

Anonymous. (2011). Punjab Agricultural Handbook. Punjab Agricultural University, Ludhiana.

Culpin, C. (1981).Farm machinery, 10th Edn., Spain: Granada Technical Books Press. Kosutic.

Destan, M.F., \& Houmy, K. (1990). Effect of design and kinematic parameters of rotary cultivators on soil structure. Soil and Tillage Research. 17:291-301.

Gopal, U.S., \& Shyam, R.K. (2012). Design optimization in rotary tillage tool system components by computer aided engineering analysis. Int. J. Environ. Sci. Dev. 3: 20-25. variables (moisture and speed ratio; passes and speed ratio; and moisture and passes) had significant effect on specific tilling energy.

\section{Conclusion}

Rotary tillage is gaining a huge importance in preparing field quickly and timely. Horizontal axis rotary tiller or a rotavator plays major role in reducing the energy requirements. In respect of this, these conclusive points can be drawn. The passes had significant effect on torque, power and specific tilling energy of rotary tiller. The clay loam soil offered higher torque, power requirements for rotary tilling process. The both soil textures at higher moisture content showed more seedbed heights compared to lower moisture contents. The higher speeds and moisture contents lower than filed capacity of soil would always help reduce the power and specific energy requirements. Since, having operated a rotary tiller at different moistures, higher moisture contents reduced the specific tilling energy substantially for sandy loam and clay loam soil.

\section{Acknowledgement}

The author is grateful for the financial assistance provided by Indian Agricultural Research Institute, ICAR- New Delhi (India). The supports and encouragements of co-authors, and Division of Agricultural Engineering are acknowledged for providing the field and soil dynamics lab for use during experiments.

Krutz, G. (2006). Design of agricultural machinery. New York: John Wiley and Sons Press.

Lee, K. S., Park, S. H., \& Lee, C. S. (2003). Strip tillage characteristics of rotary tiller blades for use in a dryland direct rice seeder. Soil \& Tillage Research. 71:25-32.

Matin, M.A., Fielke, J.M., \& Desbiolles, M. A. (2015). Torque and energy characteristics for strip-tillage cultivation when cutting furrows using three designs of rotary blade. Biosystems Engineering. 129:329-340.

Ramesh, P., Bhimwal, J.P., \& Choudhary, S. (2015). Effect of $\lambda$-ratio and depth of cut on draft, fuel consumption, power consumption and field efficiency of an offset rotavator under different type of orchards. Journal of Advances in Biology \& Biotechnology. 3(2):77-83. 
Sahay, C.S., Thomas, E.V., \& Satapathy, K.K. (2009). Performance evaluation of a novel power tiller-operated oscillatory tillage implement for dry land tillage. Bio System Engineering. 102:385-391.

Salokhe, V. M., \& Ramalingam, N. (2001). Effects of direction of rotation of a rotary tiller on properties of Bangkok clay soil. Soil and Tillage research. 63: 65-74.

Sharda, A., \& Singh, S. (2004). Effects of selected parameters on field performance of rotary tiller. Journal of Institution of Engineers. 85: 21-25.

Shiva, B., Gursahib, S.M., Apoorv, P., \& Dixit, A.(2014). Effect of Blade Shape and Rotor Speed of Rotavator on Pulverization and Mixing Quality of Soil. Agricultural Engineering Today, 38(4):25-30.
Sinha, J.P. and Ram, R.B. (1998). Performance of tillage tools energy on energy basis. IE (I). Soil Dynamics Research Committee Journal-AG. 78(1):38-40.

Sirisak, C., \& Niyamapa Tanya. (2010). Variations of torque and specific tilling energy for different rotary blades. International Agricultural Engineering Journal. 19(3): 113.

Surendra, S. (2007). Farm machinery- Principles and applications. Directorate of Information and Publications on Agriculture, Indian Council of Agricultural Research, New Delhi.

Topakci, M., Celik, H. K., \& Yilmaz, D. (2008). Stress analysis on transmission gears of a rotary tiller using finite element method. Akendiz Ünivresitesi Ziraat Fakultesi Dergisi, 21(2): 155-160 